\title{
SOME MEDICINAL - AROMATIC PLANTS SOLD IN HERBALISTS OF ORDU PROVINCE IN TURKEY AND THEIR USAGE
}

\author{
Asiye KARAEVLI ${ }^{1}$, Ayse Gul SARIKAYA ${ }^{2 *}$ \\ ${ }^{1}$ Bartin University, Faculty of Forestry, Bursa, Turkey; \\ ${ }^{2 *}$ Bursa Technical University, Faculty of Forestry, Bartin, Turkey; \\ *Corresponding Author Ayse Gul SARIKAYA, e-mail: aysegul.sarikaya@btu.edu.tr;
}

Received June 2021; Accepted July 2021; Published August 2021;

DOI: https://doi.org/10.31407/ijees11.408

\begin{abstract}
In this study, 17 herbalists from the center and some districts (Korgan-Kumru-Fatsa-Unye) of Ordu province were interviewed in order to determine the medicinal and aromatic plants sold in herbalists in Ordu province and their usage areas. As result of the interviews, it was determined that 35 taxa belonging to 19 families and they have 20 different usage areas. Families with the most used species were Lamiaceae (20\%), Apiaceae (11\%), Rosaceae (8\%) and Fabeceae (8\%). Using parts of this taxa are leaf (37\%), seed (17\%), flower (17\%), fruit (14\%), root (5\%), shell (3\%) and the stem (3\%). It has been determined that taxa are consumed as brewing (52\%), raw (20\%), powder (15\%), oil (9\%) molasses (2\%) and boiling (2\%). The species mostly sold in the herbalist shops were distinguished as Ginger (Zingiber ofinale R.), Turmeric (Curcuma longa L.), Chili pepper (Capsicum annum L., Black pepper (Piper nigrum L.), Mint (Mentha piperita L.) and Thyme (Tymus spp.). Medicinal and aromatic plants are mostly used as flu, cold, upper respiratory tract ailments, slimming-edema remover, spice, strengthening the immune system and relieving intestinal disorders.
\end{abstract}

Keywords: Ordu, herbalist, medicinal aromatic plants, Turkey. 